\title{
Soil Microbial Community Structure and Target Organisms under Different Fumigation Treatments
}

\author{
Sadikshya R. Dangi, ${ }^{1,2}$ James S. Gerik, ${ }^{1}$ Rebecca Tirado-Corbalá, ${ }^{1,3}$ and Husein Ajwa ${ }^{2}$ \\ ${ }^{1}$ USDA-ARS, 9611 S. Riverbend Avenue, Parlier, CA 93648, USA \\ ${ }^{2}$ University of California, Davis, 1636 East Alisal Street, Salinas, CA 93905, USA \\ ${ }^{3}$ Crops and Agro-Environmental Science Department, University of Puerto Rico-Mayagüez, Box 9000, Mayagüez, PR 00681, USA
}

Correspondence should be addressed to Sadikshya R. Dangi; sadikshya.dangi@gmail.com

Received 12 February 2015; Accepted 13 March 2015

Academic Editor: Rafael Clemente

Copyright (C) 2015 Sadikshya R. Dangi et al. This is an open access article distributed under the Creative Commons Attribution License, which permits unrestricted use, distribution, and reproduction in any medium, provided the original work is properly cited.

\begin{abstract}
Producers of several high-value crops in California rely heavily on soil fumigants to control key diseases, nematodes, and weeds. Fumigants with broad biocidal activity can affect both target and nontarget soil microorganisms. The ability of nontarget soil microorganisms to recover after fumigation treatment is critical because they play an important role in sustaining the health of agricultural and natural soil systems. Fumigation trial was conducted in Parlier, CA, and the study focuses on the effects of different rates of Telone $\mathrm{C} 35$ and also methyl bromide fumigation with polyethylene (PE) and totally impermeable film (TIF) tarps on target and nontarget soil microorganisms using field samples. Results indicated that the populations of target organisms, such as Fusarium oxysporum and Pythium spp., were reduced at all rates of fumigants. Phospholipid fatty acid (PLFA) analysis indicated that all major nontarget soil microbial groups such as Gram positive bacteria, Gram negative bacteria, fungi, and arbuscular mycorrhizal fungi (AMF) were affected by methyl bromide (MeBr) fumigation treatment. In general, the effects of Telone C35 (299 L/ha) under PE tarp had the least impact on microbial community structure and better effect on controlling target microorganisms and, therefore, indicated the better option among fumigation treatments.
\end{abstract}

\section{Introduction}

Fumigants are used to control a wide array of soil-borne pests including nematodes, pathogens, and weeds. In California and Florida, soil fumigants are extensively used to grow strawberries, tomatoes, and other high value cash crops [1]. Therefore, to ensure better crop yield and provide greater benefits to growers, soil fumigation has become an important agricultural practice worldwide [2]. Most of the fumigants are known to have broad biocidal activity $[3,4]$, but their effect on soil microbial community structure was not known until recently [5-7]. After the phase-out of $\mathrm{MeBr}$ in the United States by January 1, 2005, several other replacements are now in use such as chloropicrin (CP), Telone (1,3dichloropropene or 1,3-D), methyl isothiocyanate (MITC), and dimethyl disulfide (DMDS). Studies by Ibekwe et al. [3] indicate that $\mathrm{MeBr}$ has the greatest impact on soil microbial communities and 1,3-D has the least impact. Also, a study by
Dangi et al. [8] concluded that DMDS fumigation did not impact the activity of beneficial microorganisms. The effects of other recently used fumigants with various surface sealing techniques on microbial community structure and biomass are still unknown.

The effects of fumigant on beneficial nontarget organisms at the field application are largely unknown due to the problems associated with sample collection soon after the application of fumigants and partly due to the lack of appropriate methods to describe microbial community composition [3,9]. Genome-based and PLFA approaches can be used for analysis of community structure. Phospholipid fatty acid analysis provides a quantitative biomass measurement, is very sensitive to environmental perturbations, can detect shifts in microbial community composition following treatments [10], and may even be more sensitive in detecting shifts in microbial community composition when compared to nucleic acid based methods [11, 12]. 
The microbial community composition changes as a result of fumigant applications may lead to changes in the functional diversity of that community and the soil quality [1]. Microorganisms in soil are crucial in sustaining the health of natural and agricultural soil systems [1] and significantly contribute to nutrient cycling, organic matter decomposition, plant nutrient uptake, and maintenance of soil structure $[13$, 14]. Therefore, it is very important for them to recover after treatment with fumigants for the development of healthy soils.

Fumigation treatments cause alterations in soil microbial populations and can contribute to physical, chemical, and biological changes in soil $[4,15,16]$. Several perturbations during fumigant application are either through tractormounted shanks or through irrigation systems and, also, the use of plastic tarps can impact these soil variables [17]. Furthermore, the impact of fumigant application methods on soil properties needs to be given serious consideration.

Soil fumigation is needed to control soil-borne pathogens such as Pythium and Fusarium species [18]. These pathogens have a broad host range, causing general root or crown rots. Pythium spp. tend to attack juvenile or herbaceous plants, while Fusarium solani causes a generalized root rot and Fusarium oxysporum causes vascular wilt. All of the pathogens are capable of causing yield reductions of most ornamental crops currently grown in fumigated soil.

The effects of fumigant on the soil microbial community structure and biomass as well as target soil pathogens are important to gain a broad understanding of the biocidal activity of these fumigants. Therefore, the objectives of this study were to determine the efficacy of fumigation treatments on both target (Pythium spp. and Fusarium oxysporum) and nontarget microorganisms (Gram positive bacteria, Gram negative bacteria, fungi, AMF, actinomycetes, and protozoa) in soil and to compare these organisms in fumigated versus nonfumigated control soils. We hypothesized that (1) methyl bromide and high rate of Telone C 35 would be effective to control Fusarium oxysporum and Pythium spp., (2) fumigated plots would result in lower microbial biomass than control soils, and (3) microbial community structure in fumigated soil would be different than in nonfumigated soils.

\section{Materials and Methods}

2.1. Field Trial, Treatment, and Plot Description. Fumigation trial was conducted in November 2011 at the USDA-ARS San Joaquin Valley Agricultural Sciences Center, Parlier, CA. The field plot tests represent the actual field conditions and, in the present study as stated in the previous study by Gao et al. [17], treatments were replicated three times with randomized complete block design to reduce errors from field variability. Fumigants were shank applied and the plots were $30 \mathrm{~m}$ long and $584 \mathrm{~mm}$ wide. The soil was a Hanford sandy loam (coarse-loamy, mixed, superactive, nonacid, and thermic Typic Xerorthents), a common soil type of the east side of San Joaquin Valley. This soil had $\mathrm{pH}$ 8.0, $45 \mathrm{ppm}$ dissolved organic carbon (DOC), and 22$30 \%$ of water holding capacity (WHC). Fumigation and
TABLE 1: Fumigant type, application rate, and method used in Parlier, CA, USA.

\begin{tabular}{lccc}
\hline Treatment & $\begin{array}{l}\text { Application } \\
\text { rates (L/ha) }\end{array}$ & $\operatorname{Tarp}^{\dagger}$ & Application method \\
\hline $\begin{array}{l}\text { Control } \\
\begin{array}{l}\text { Telone C35 } \\
\text { (TFNB) }\end{array}\end{array}$ & 0 & Bare & - \\
$\begin{array}{l}\text { Telone C35 } \\
\text { (TFNPE) }\end{array}$ & 449 & Bare & Shank with $\mathrm{N}_{2}$ delivery \\
$\begin{array}{l}\text { Telone C35 } \\
\text { (T2/3NB) }\end{array}$ & 229 & PE & Shank with $\mathrm{N}_{2}$ delivery \\
$\begin{array}{l}\text { Telone C35 } \\
\text { (T2/3NPE) }\end{array}$ & 229 & PE & Shank with $\mathrm{N}_{2}$ delivery \\
$\begin{array}{l}\text { Telone C35 } \\
\text { (T2/3NTIF) }\end{array}$ & 229 & TIF & Shank with $\mathrm{N}_{2}$ delivery \\
$\begin{array}{l}\text { Telone C35 } \\
\text { (T2/3COTIF) }\end{array}$ & 299 & TIF & Shank with $\mathrm{CO}_{2}$ delivery \\
$\begin{array}{l}\text { MeBr } \text { CP } \\
(\text { MeBrPE })\end{array}$ & 499 & PE & Shank \\
\hline
\end{tabular}

${ }^{\dagger} \mathrm{MeBr}$, methyl bromide; $\mathrm{CP}$, chloropicrin; PE, polyethylene film; TIF, totally impermeable film.

tarp installation were done with commercial application equipment and materials (TriCal, Inc., Hollister, CA). Telone C35 (Dow AgroSciences, Indianapolis, IN; 63.4\% 1,3-D and $34.7 \% \mathrm{CP}$ ) was applied at a depth of $45 \mathrm{~cm}$ with shanks spaced $50 \mathrm{~cm}$ apart at rates of 449 (full or maximum label rate) and 299 (2/3 rate) L/ha. The 2/3 rates included carbonated fumigants by adding $\mathrm{CO}_{2}$ to fumigant tank with the purpose to enhance fumigant dispersion in soil.

After fumigation, the Telone C35 plots were covered with 1-mil PE tarp (TriCal, Inc., Hollister, CA) or TIF tarp (VaporSafe; Raven Industries, Sioux Falls, SD) or left bare. Methyl bromide:CP (67\%:33\%) was applied at $449 \mathrm{~L} / \mathrm{ha}$ with a Nobel plow and covered with PE tarp. The treatments and other fumigation descriptions are given in Table 1. After about 4 weeks of field monitoring on emission and soil fumigant movement, the tarps were cut on 22 November 2011 and removed one week later.

2.2. Sampling. Soil samples were collected after the tarps were removed from upper $0-15 \mathrm{~cm}$ depth. The experiment was arranged as a randomized complete block design with three replications in each treatment with total of 24 plots. Three transects were randomly placed on each plot and soil samples were collected from three equally spaced points along each transect and were composited. Samples for PLFA analysis were placed in sealed plastic bags, stored on dry ice immediately after collection, and then returned to the laboratory where they were placed at $-20^{\circ} \mathrm{C}$ freezer until analyzed.

\subsection{Target Organisms and Soil Physicochemical Analysis.} Determination of Fusarium oxysporum and Pythium spp. populations was performed using dilution plating on Komada's medium [19] and $\mathrm{P}_{5} \mathrm{ARP}$ medium [20]. Soil pH was determined by using 1:1 soil to deionized water (DI) 
TABle 2: General properties of Hanford sandy loam at Parlier, California.

\begin{tabular}{lcccccccccc}
\hline Treatment & $\mathrm{pH}$ & $\begin{array}{c}\mathrm{EC} \\
\mu \mathrm{S}\end{array}$ & $\mathrm{TC}$ & $\mathrm{TN}$ & $\begin{array}{c}\mathrm{DOC} \\
\mathrm{ppm}\end{array}$ & $\mathrm{Ca}$ & $\mathrm{K}$ & $\begin{array}{c}\mathrm{Mg} \\
\mathrm{mg} / \mathrm{kg}\end{array}$ & $\mathrm{Na}$ \\
\hline Control & $8.11^{*}$ & $367 \mathrm{~b}$ & $0.42 \mathrm{~b}$ & $0.06 \mathrm{~b}$ & 35.3 & $29.0 \mathrm{~b}$ & 152 & $6.06 \mathrm{~b}$ & 6.46 & 1.84 \\
MeBrPE & 7.89 & $615 \mathrm{a}$ & $0.01 \mathrm{~b}$ & $0 \mathrm{~b}$ & 57.6 & $46.9 \mathrm{a}$ & 198 & $10.34 \mathrm{a}$ & 8.01 & 3.21 \\
T 2/3 COTIF & 8.08 & $378 \mathrm{~b}$ & $0.42 \mathrm{~b}$ & $0 \mathrm{~b}$ & 52.0 & $28.1 \mathrm{~b}$ & 168 & $6.26 \mathrm{~b}$ & 6.71 & 2.02 \\
T 2/3 NB & 8.07 & $531 \mathrm{ab}$ & $0.18 \mathrm{~b}$ & $0.06 \mathrm{~b}$ & 40.7 & $38.8 \mathrm{ab}$ & 181 & $8.35 \mathrm{ab}$ & 9.57 & 3.28 \\
T 2/3 NPE & 8.12 & $389 \mathrm{~b}$ & $2.59 \mathrm{a}$ & $0.30 \mathrm{a}$ & 44.7 & $29.2 \mathrm{~b}$ & 168 & $6.26 \mathrm{~b}$ & 6.68 & 1.86 \\
T 2/3 NTIF & 8.11 & $529 \mathrm{ab}$ & $0.13 \mathrm{~b}$ & $0.05 \mathrm{~b}$ & 38.8 & $38.9 \mathrm{ab}$ & 225 & $8.12 \mathrm{ab}$ & 7.35 & 2.44 \\
TFNB & 8.10 & $469 \mathrm{ab}$ & $0.44 \mathrm{~b}$ & $0.07 \mathrm{ab}$ & 37.2 & $34.6 \mathrm{~b}$ & 167 & $7.28 \mathrm{~b}$ & 7.52 \\
TFNPE & 8.03 & $462 \mathrm{ab}$ & $0.30 \mathrm{~b}$ & $0.08 \mathrm{ab}$ & 55.3 & $32.5 \mathrm{~b}$ & 185 & $7.13 \mathrm{~b}$ & 7.47 & 2.33 \\
Pr $>$ F & 0.29 & $0.012^{*}$ & $0.002^{*}$ & $0.007^{*}$ & 0.57 & $0.042^{*}$ & 0.18 & $0.049^{*}$ & 0.69 & 0.30 \\
SE & 0.07 & 44.4 & 0.42 & 0.05 & 9.52 & 3.89 & 17.4 & 0.90 & 1.21 & 0.49 \\
\hline
\end{tabular}

${ }^{*}$ Means followed by different letters in a column are significantly different by Tukey's test at $P<0.05$.

EC, electrical conductivity; TC, total carbon; TN, total nitrogen; DOC, dissolved organic carbon, Ca, calcium; K, potassium; Mg, magnesium; Na, sodium; S, sulfur.

MeBrPE (methyl bromide, PE tarp), T2/3COTIF (Telone C35, 2/3 rate, CO2 delivery, TIF tarp), T2/3 NB (Telone C35, 2/3 rate, N2 delivery, bare), T2/3NPE (Telone C35, 2/3 rate, N2 delivery, PE tarp), T2/3NTIF (Telone C35, 2/3 rate, N2 delivery, TIF tarp), TFNB (Telone C35, full rate, N2 delivery, bare), and TFNPE (Telone C35, full rate, N2 delivery, PE tarp).

water ratio. Dissolved organic carbon was determined after saturating the soil with DI water (1:1 soil: water) for 24 hours, shaken for a one hour on a reciprocal shaker, and filtered through a Whatman number 42 filter. Carbon recovered in the water extract was determined by using Fusion Total Organic Carbon Analyzer from Teledyne Tekmar. Total nitrogen (TN) and total carbon (TC) contents were determined by dry combustion with a Flash 2000 N \& C Soil Analyzer (Thermo Scientific, Pittsburgh, $\mathrm{PA})$. Macronutrients such as $\mathrm{Ca}, \mathrm{Mg}, \mathrm{S}, \mathrm{K}$, and $\mathrm{Na}$ were determined using ICP-OES (Varian, Palo Alto, CA).

2.4. Soil PLFA Analysis. Phospholipid fatty acids were extracted from $10 \mathrm{~g}$ soil samples using a modified BlighDyer methodology [21]. Fatty acids were directly extracted from soil samples using a mixture of chloroform : methanol: phosphate buffer $(1: 2: 0.8)$. Phospholipid fatty acids were separated from neutral and glycolipid fatty acids in a solid phase extraction column. After mild alkaline methanolysis, PLFA samples were qualitatively and quantitatively analyzed using an Agilent 6890 gas chromatograph (Agilent Technologies, Palo Alto, CA) and fatty acids were identified by retention time according to the MIDI eukaryotic method (MIDI Inc., Newark, NJ).

Individual PLFA signatures were used to quantify the abundances of specific microbial groups in soil samples. Gram positive bacteria were identified and quantified by the presence of iso- and anteiso-branched fatty acids, Gram negative bacteria with monounsaturated fatty acids. Fungi were identified and quantified with 18:2 $\omega 6 \mathrm{c}$, arbuscular mycorrhizal fungi (AMF) with 16:1 $\omega 5 \mathrm{c}$, and actinomycetes with 10-methyl fatty acids [22-25].

\section{Data Analysis}

Statistical analysis was undertaken using SAS 9.1 [26]. PLFA peak areas were combined into biomarker groups. Analysis of variance (ANOVA) was conducted on total PLFA and on each biomarker group in order to see how the total microbial biomass and the biomass of each group of organisms were affected by different fumigation treatments. A multivariate method (canonical discriminant analysis) was used to compare soil microbial communities from the different concentrations/fumigants and to determine similarity among microbial communities in the control and fumigated soils. In this analysis, MANOVA on the absolute area of each biomarker was used to identify the linear combination of variables (referred to as canonical variates) that best separated the soil microbial community structure at the different plots. The canonical variates are graphed to summarize group differences [27-29]. All statistical analyses were evaluated at the $P<0.05$ significance level.

\section{Results}

4.1. General Soil Characteristics. In order to understand the impact of soil fumigants, soil characteristics, macronutrients, and losses of TC, TN, and DOC were determined (Table 2). Total carbon and TN were significantly lower in methyl bromide:chloropicrin fumigation with PE tarp (MeBrPE) and all rates of Telone C35 except in 2/3 application rate of Telone C35 with PE tarp (T2/3 NPE). Soil $\mathrm{pH}$ and DOC did not significantly differ among treatments. Among the macronutrients studied, soil $\mathrm{Ca}$ and $\mathrm{Mg}$ increased significantly in MeBrPE treatment $(46.0 \mathrm{mg} \mathrm{Ca} / \mathrm{kg}$ and $10.34 \mathrm{mg} \mathrm{Mg} / \mathrm{kg}$ ) compared to carbonated Telone C35 with $2 / 3$ application rate with TIF tarp (T2/3COTIF) treatment $(28 \mathrm{mg} \mathrm{Ca} / \mathrm{kg}$ and $6.26 \mathrm{mg} \mathrm{Mg} / \mathrm{kg})$. No significant differences were observed in $\mathrm{K}, \mathrm{Na}$, and $\mathrm{S}$ among treatments.

4.2. Effects of Fumigants on Target Microorganisms. Populations of Fusarium oxysporum and Pythium spp. were significantly $(P<0.05)$ reduced in methyl bromide : chloropicrin fumigation with $\mathrm{PE}$ tarp, Telone $\mathrm{C} 35$ with $2 / 3$ application rate, 


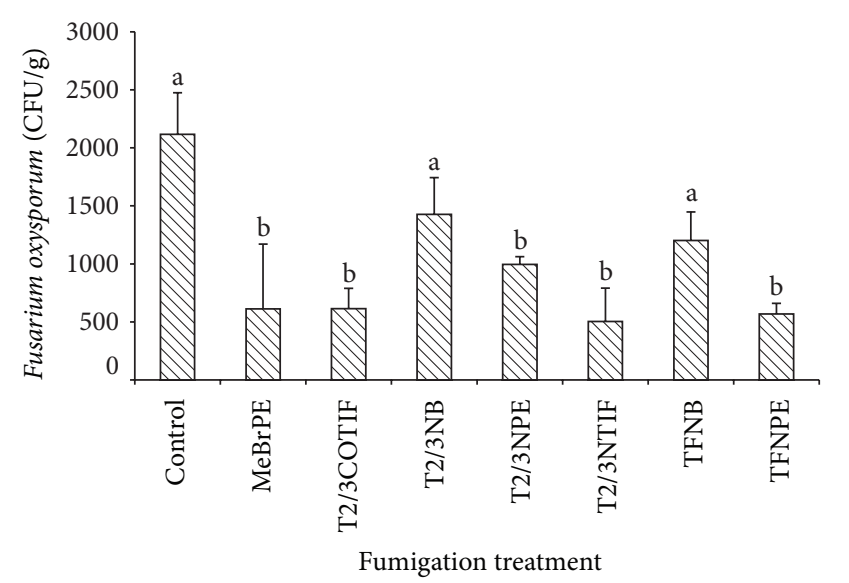

FIgUre 1: Populations of Fusarium oxysporum in soil samples collected from plots fumigated with MeBrPE (methyl bromide, $\mathrm{PE}$ tarp), T2/3COTIF (carbonated Telone C35, 2/3 rate, TIF tarp), T2/3 NB (Telone C35, 2/3 rate, bare), T2/3NPE (Telone C35, 2/3 rate, PE tarp), T2/3NTIF (Telone C35, 2/3 rate, TIF tarp), TFNB (Telone C35, full rate, bare), and TFNPE (Telone C35, full rate, PE tarp) liter per hectare. Different letters indicate significant differences $(P<0.05)$. Error bar indicates standard error.

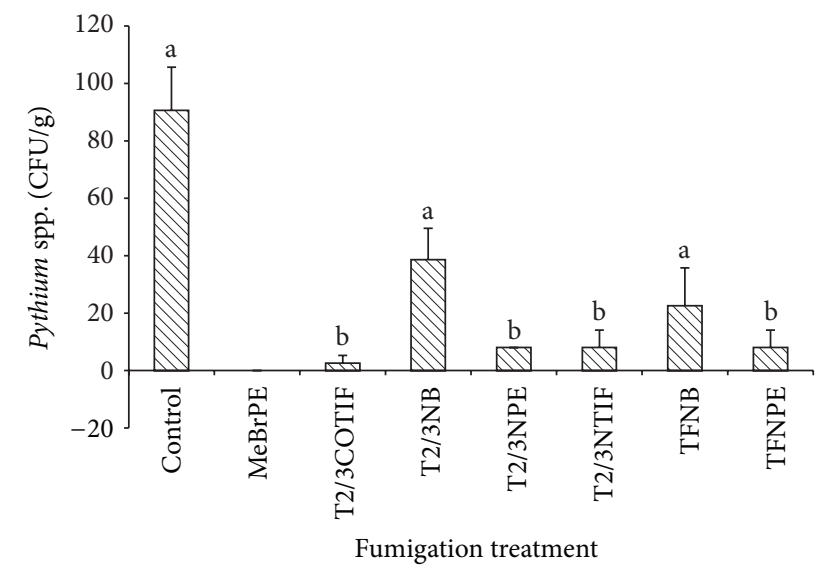

Figure 2: Populations of Pythium spp. in soil samples collected from plots fumigated with MeBrPE (methyl bromide, PE tarp), T2/3COTIF (carbonated Telone C35, 2/3 rate, TIF tarp), T2/3 NB (Telone $\mathrm{C} 35,2 / 3$ rate, bare), T2/3NPE (Telone C35, 2/3 rate, PE tarp), T2/3NTIF (Telone C35, 2/3 rate, TIF tarp), TFNB (Telone C35, full rate, bare), and TFNPE (Telone $\mathrm{C} 35$, full rate, PE tarp) liter per hectare. Different letters indicate significant differences $(P<0.05)$. Error bar indicates standard error.

and full application rate with PE and TIF tarps as compared to $2 / 3$ and full application rate without any tarp and control plots (Figures 1 and 2). Furthermore, different tarps played an important role along with the fumigants as bare (without tarp) plots have more target microorganisms compared to PE or TIF tarp.

4.3. Phospholipid Fatty Acid Biomarker Values. Total PLFA concentration ranged from 3.497 to $6.4 \mu \mathrm{g} \mathrm{g}^{-1}$ soil (Figure 3). Methyl bromide (MeBrPE), T2/3COTIF, 2/3 application rate

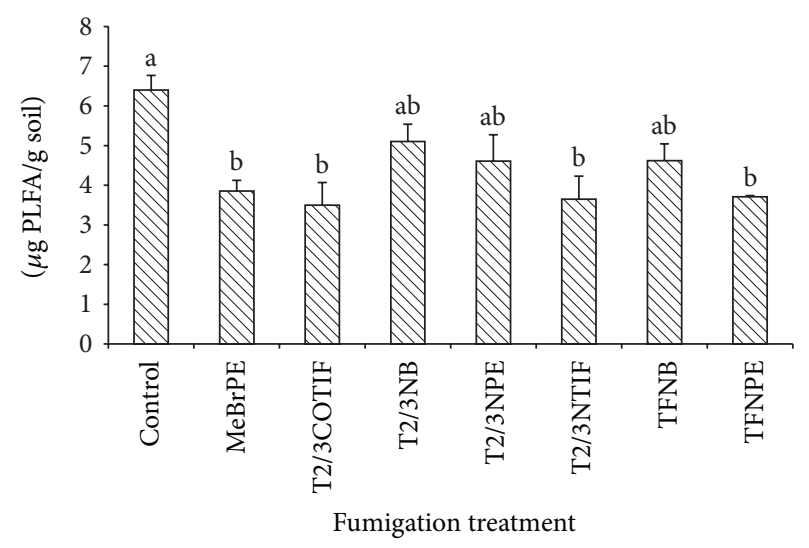

FIGURE 3: Total amount of PLFAs from plots fumigated with MeBrPE (methyl bromide, PE tarp), T2/3COTIF (carbonated Telone C35, 2/3 rate, TIF tarp), T2/3 NB (Telone C35, 2/3 rate, bare), T2/3NPE (Telone C35, 2/3 rate, PE tarp), T2/3NTIF (Telone C35, $2 / 3$ rate, TIF tarp), TFNB (Telone C35, full rate, bare), and TFNPE (Telone C35, full rate, PE tarp) liter per hectare. Different letters indicate significant differences $(P<0.05)$. Error bar indicates standard error.

of Telone C35 with TIF tarp (T2/3NTIF), and full application rate of Telone C35 with PE tarp (TFNPE) contained the lowest PLFA and the nonfumigated control plot had the highest PLFA content. Biomarker PLFAs for both Gram positive and Gram negative bacteria were at their lowest concentration in soil from the MeBrPE, T2/3COTIF, T2/3NTIF, and TFNPE (Figures 4(a) and 4(b)). Soils from $2 / 3$ application rate of Telone C35 without any tarp (T2/3NB), T2/3NPE, and full application rate of Telone C35 without any tarp (TFNB) had significantly greater concentrations of both Gram positive $(P<0.05)$ and Gram negative $(P<0.05)$ bacterial biomarker PLFA compared to other fumigation treatments. Mean values for amounts of both the fungal biomarker and the arbuscular mycorrhizal fungal biomarker (Figures 4(c) and $4(\mathrm{~d})$ ) were similar to the patterns observed in Gram positive and Gram negative biomarker. The variations to this were the actinomycetes PLFA biomarker (Figure 4(e)), where the concentrations in the control plot were significantly lower than $\mathrm{MeBrPE}$ and high rates of Telone C35. Unlike the other PLFAs, mean concentration of actinomycetes biomarker was significantly greater in soils fumigated with $\mathrm{MeBrPE}$ compared to control plot.

4.4. Microbial Community Structure. Canonical multivariate analysis indicates differences in soil microbial community structure between the control and fumigated plots (Figure 5). Canonical multivariate analysis suggests that soil microbial communities in MeBrPE fumigated plot are significantly different compared to control and Telone $\mathrm{C} 35$ fumigated plots $(P<0.05)$. Plot fumigated with T2/3NPE is more similar to T2/3NTIF, TFNB, and TFNPE as shown by the closer proximity of biomarker clusters to one another (Figure 5). Lower relative abundance of bacteria and fungi was found in plots fumigated with $\mathrm{MeBr}$. 


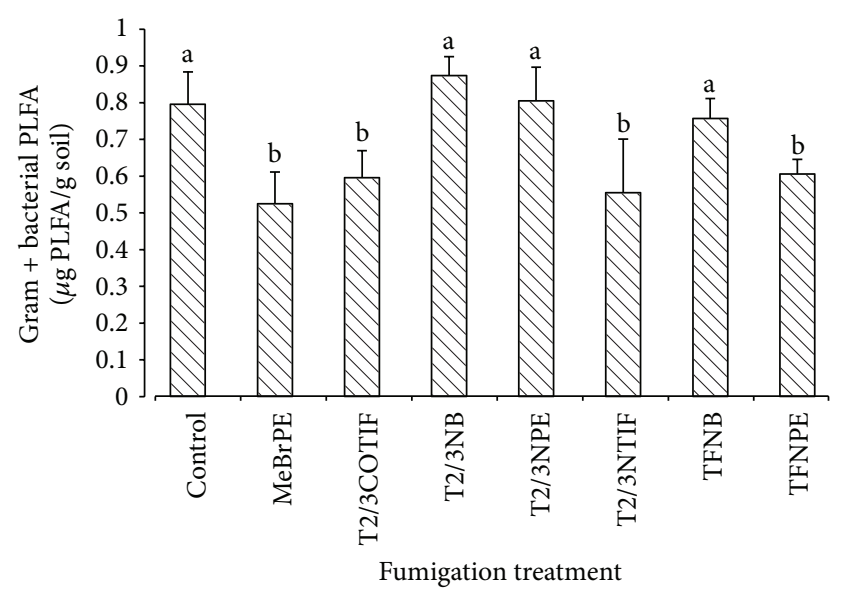

(a)

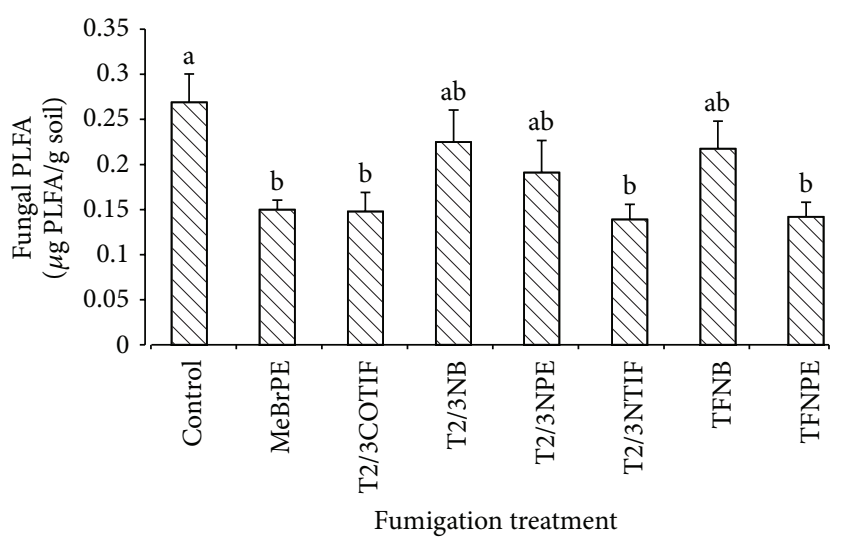

(c)

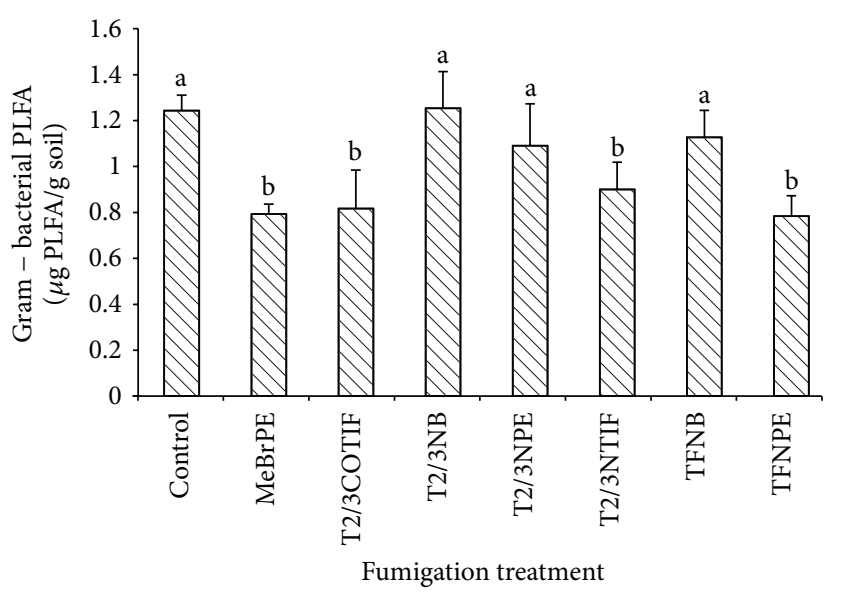

(b)

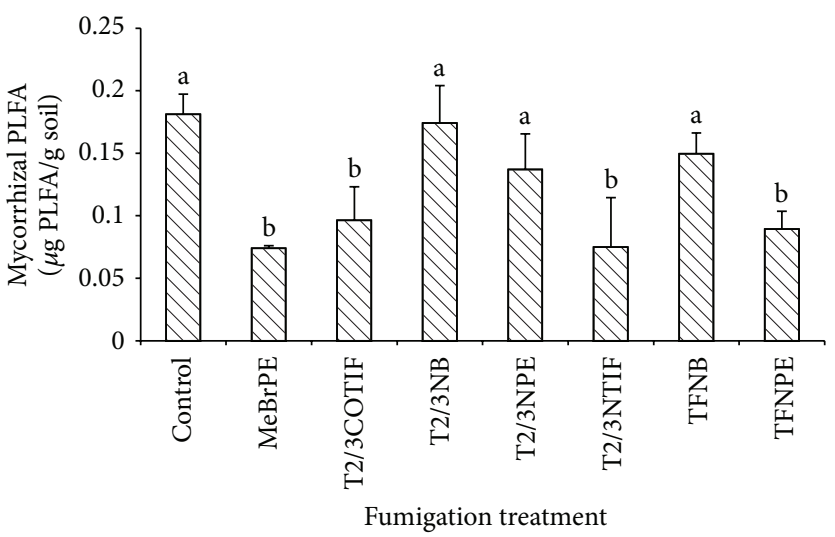

(d)

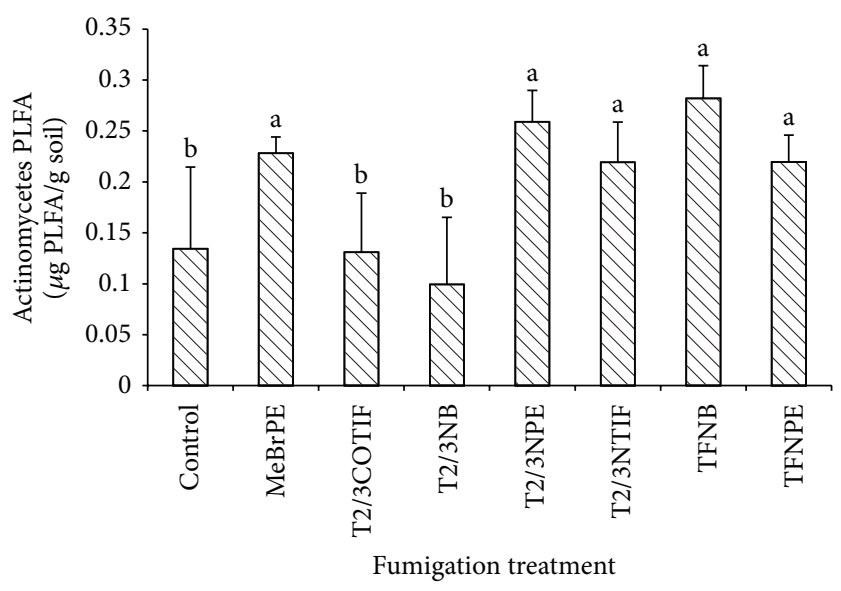

(e)

Figure 4: Gram positive (a), Gram negative (b), fungal (c), mycorrhizal (d), and actinomycetes (e) PLFA from plots fumigated with MeBrPE (methyl bromide, PE tarp), T2/3COTIF (carbonated Telone C35, 2/3 rate, TIF tarp), T2/3 NB (Telone C35, 2/3 rate, bare), T2/3NPE (Telone C35, 2/3 rate, PE tarp), T2/3NTIF (Telone C35, 2/3 rate, TIF tarp), TFNB (Telone C35, full rate, bare), and TFNPE (Telone C35, full rate, PE tarp) liter per hectare. Different letters indicate significant differences $(P<0.05)$. Error bar indicates standard error.

\section{Discussion}

Application of fumigants results in a decline of target and nontarget soil microorganisms and biomass. Previous studies on the effect of fumigants on soil microorganisms were limited to the laboratory microcosm experiment $[3,30$, 31], but the effect of fumigants on the shift in microbial community structure under field conditions has not been documented for many commercial fumigants and application methods. Ibekwe et al. [3] found negative effects of 1,3-D and 

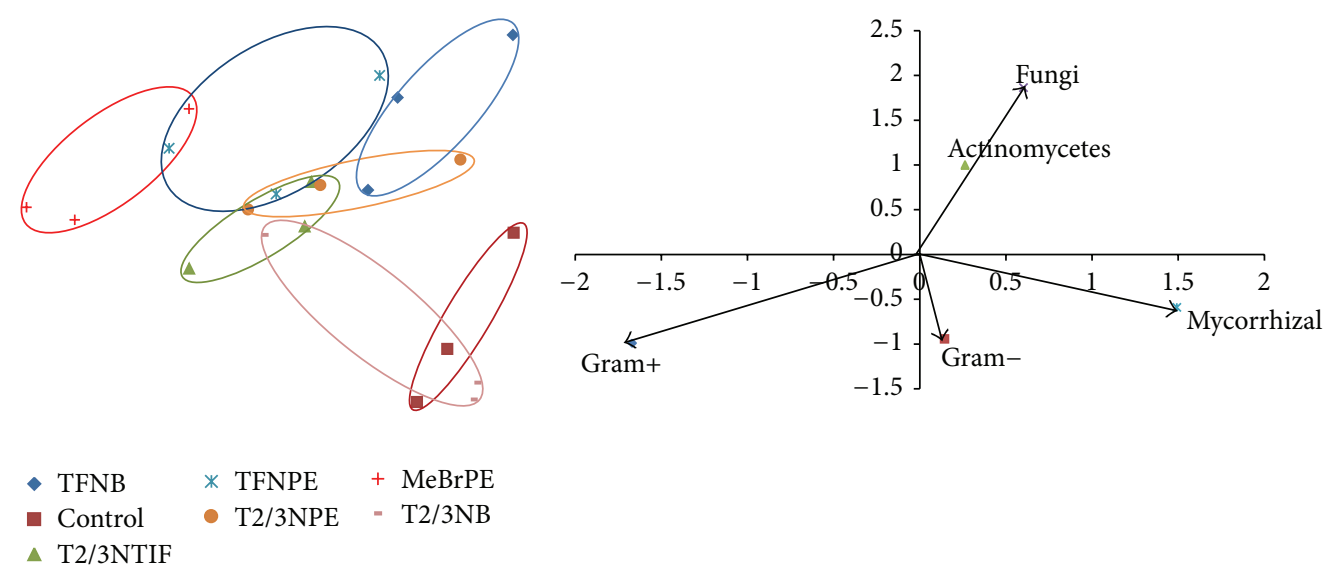

FIGURE 5: Canonical multivariate analysis of variance of PLFA biomarkers for a Parlier trial. Vectors represent standardized canonical coefficients and indicate the relative contribution of each biomarker group to each canonical variate.

$\mathrm{CP}$ on actinomycetes and of methyl isothiocyanate (MITC) and $\mathrm{MeBr}$ on Gram negative bacteria using a laboratory microcosm experiment. There are few studies on either target $[3,5]$ or nontarget $[18,32]$ soil microorganisms; however, effects on both target and nontarget soil microorganisms using field samples are not well understood. Our study evaluated both target soil microorganisms such as species of Pythium spp. and Fusarium oxysporum and nontarget soil microorganisms such as Gram positive, Gram negative, AMF, fungi, and actinomycetes using field samples. Soil microbial biomass (total concentration of PLFAs), although not significant, declined after application of soil fumigants as compared to nonfumigated control soil. All microbial groups, except actinomycetes, had lower concentration of microbial biomass after fumigation compared to nonfumigated control soils. Early laboratory studies by Ibekwe et al. [3] evaluated the effect of different fumigants, such as MeBr, MITC, 1,3-D, and $\mathrm{CP}$, on soil microbial communities and found that $\mathrm{MeBr}$ had the greatest impact and 1,3-D has the least impact. Similarly, other studies have observed the decline in microbial biomass after fumigation with different fumigants [5]. As samples are not allowed to be collected immediately after $\mathrm{MeBr}$ or other fumigation, studies have relied on a laboratory microcosm experiment for basic results after fumigation treatments to reflect field conditions $[3,5]$. The present study evaluated microbial community structure and biomass after fumigation treatments using field samples. Subsequently, samples were collected only after about 4 weeks of fumigation; therefore, the immediate impact on microbial community biomass and structure could not be monitored.

The present study showed that the method of application of fumigants and the use of tarp seem to have played a role in microbial community structure. Because of their high volatility, soil fumigants are subjected to high emission losses and the plastic tarps play an important role as a surface barrier in minimizing emissions [17]. In the Parlier trial, two different tarps were used, PE and TIF. Study also found that 2/3 application rate of Telone C35 with PE tarp and bare plots had greater concentrations of Gram positive bacteria, Gram negative bacteria, fungi, and mycorrhizal PLFA as compared to TIF tarp. Moreover, the use of PE and TIF tarp significantly decreased the target organisms in all the fumigants used.

The populations of Pythium and Fusarium were reduced with all fumigants. However, fumigants were much effective in controlling Pythium spp. compared to F. oxysporum as observed in the past experiments [18]. Bare plot contained higher F. oxysporum and Pythium spp. compared to TIF and PE tarp.

The ability of soil microorganisms such as bacteria and fungi to improve after treatment with pesticide is critical for the development of healthy soils [1]. Our study showed that fungal and AMF biomass tends to significantly decrease in fumigated soils. Comparable results were reported by Klose et al. [5] on the effect of fumigation on fungal and AMF populations which may be significant for management decisions as there are numerous benefits of fungi and AMF on crop production and soil health [33]. Similar trend was observed for Gram negative and Gram positive bacterial biomass. Previous studies on bacterial populations shifts are variable [34], as some reports have suggested that the soil bacterial community after fumigation is dominated by Gram negative bacteria [35] while other studies have reported that Gram positive bacteria recover preferentially after fumigation $[3,31,36]$. Different trend was observed in the actinomycetes PLFA biomarker, where the concentrations in the control plot were significantly lower than $\mathrm{MeBr}$ and high rates of Telone C35. Several other studies have found an increase in actinomycetes numbers following fumigation [10, 31].

Canonical variate analysis of PLFA data indicates differences in soil microbial community structure between the control and fumigated plots (Figure 5). Canonical analysis suggests that soil microbial communities in the control and T2/3 NB plots were completely different than plots fumigated with $\mathrm{MeBr}$ and Telone C35 with tarps. Data points for the control plots were more separated than treated plots. This supports the hypothesis that soil fumigants can be harmful to soil microbial communities, at least for a short term after fumigation.

Microorganisms possess the ability to give an integrated measure of soil health [37] and abiotic factors can frequently 
alter the nature of populations and their biochemical potential [14]. Some of the environmental variables influencing soil microorganisms include $\mathrm{pH}, \mathrm{TC}, \mathrm{TN}, \mathrm{DOC}$, and nutrient supply. Soil pH did not significantly differ among treatments. Soil TC increased in higher rate of T2/3 NPE treatments and soil TN increased in lower rate of T2/3 NPE treatments. Soil nitrogen input is mainly derived from the following sources: $\mathrm{N}$ deposition [38]; litter decomposition [39]; and bacterial fixation of atmospheric $\mathrm{N}_{2}$ [40]. In our study, the main reason for the increase in soil $\mathrm{N}$ and $\mathrm{C}$ was probably due to samples containing leaves, roots, or other tissues in soil. Also, we observed little change in DOC concentration among different treatments. MeBrPE treatment contained significantly greater $\mathrm{Ca}$ and $\mathrm{Mg}$ as was observed in the previous study by Ragab and Okasha [41], where they found a considerable increase in the content of macronutrients, especially $\mathrm{Ca}$ and $\mathrm{Mg}$, in the fumigated soils compared to the nonfumigated control soil.

\section{Conclusion}

Research on the impact of broad biocidal activity of fumigants on soil microbial communities using field samples is unknown. The findings from the present study provide a biocidal activity of fumigants in field conditions. Our data have shown that the populations of target organisms were reduced at all rates of fumigants. Moreover, among different rates of Telone C35, T2/3NPE was considered a better option due to having the least impact on microbial community structure and better efficiency in controlling typical soilborne plant pathogens such as Pythium spp. and Fusarium oxysporum.

Abbreviations
EC: Electrical conductivity
TC: Total carbon
TN: Total nitrogen
DOC: Dissolved organic carbon
MeBr: Methyl bromide
CP: Chloropicrin
PE:

\section{Conflict of Interests}

The authors declare that there is no conflict of interests regarding the publication of this paper.

\section{Acknowledgments}

The authors would like to acknowledge Dr. Suduan Gao, USDA-ARS-SJVASC, Parlier, CA, for providing research site and research guidance and Mrs. Patricia Mungur and Mrs. Mary Terrazas for assistance with field and lab work. Also, the cooperation of Dr. Peter D. Stahl and Soil Ecology Laboratory at the University of Wyoming for gas chromatography analysis was greatly appreciated. They also acknowledge the funding assistance provided by the Pacific Area-Wide Pest Management program for Integrated Methyl Bromide Alternatives to conduct this research.

\section{References}

[1] A. M. Ibekwe, "Effects of fumigants on non-target organisms in soil," in Advances in Agronomy, vol. 83, pp. 1-35, Elsevier, 2004.

[2] H. Ajwa, W. J. Ntow, R. Qin, and S. Gao, "Properties of soil fumigants and their fate in the environment," in Hayes' Handbook of Pesticide Toxicology, pp. 315-330, Elsevier, San Diego, Calif, USA, 2010.

[3] A. M. Ibekwe, S. K. Papiernik, J. Gan, S. R. Yates, C.-H. Yang, and D. E. Crowley, "Impact of fumigants on soil microbial communities," Applied and Environmental Microbiology, vol. 67, no. 7, pp. 3245-3257, 2001.

[4] J. P. E. Anderson, "Side-effects of pesticides on carbon and nitrogen transformations in soils," in Proceedings of the International Symposium on Environmental Aspects of Pesticide Microbiology, pp. 61-67, Swedish University of Agricultural Science, Uppsala, Sweden, August 1992.

[5] S. Klose, V. Acosta-Martínez, and H. A. Ajwa, "Microbial community composition and enzyme activities in a sandy loam soil after fumigation with methyl bromide or alternative biocides," Soil Biology and Biochemistry, vol. 38, no. 6, pp. 12431254, 2006.

[6] S. A. Fennimore, M. J. Haar, and H. A. Ajwa, "Weed control in strawberry provided by shank- and drip-applied methyl bromide alternative fumigants," HortScience, vol. 38, no. 1, pp. 55-61, 2003.

[7] M. J. Haar, S. A. Fennimore, H. A. Ajwa, and C. Q. Winterbottom, "Chloropicrin effect on weed seed viability," Crop Protection, vol. 22, no. 1, pp. 109-115, 2003.

[8] S. R. Dangi, R. Tirado-Corbala, J. A. Cabrera, D. Wang, and J. Gerik, "Soil biotic and abiotic responses to dimethyl disulfide spot drip fumigation in established grape vines," Soil Science Society of America Journal, vol. 78, no. 2, pp. 520-530, 2014.

[9] R. S. Dungan, A. M. Ibekwe, and S. R. Yates, "Effect of propargyl bromide and 1,3-dichloropropene on microbial communities in an organically amended soil," FEMS Microbiology Ecology, vol. 43, no. 1, pp. 75-87, 2003.

[10] R. E. Drenovsky, R. A. Duncan, and K. M. Scow, "Soil sterilization and organic carbon, but not microbial inoculants, change microbial communities in replanted peach orchards," California Agriculture, vol. 59, no. 3, pp. 176-181, 2005.

[11] P. W. Ramsey, M. C. Rillig, K. P. Feris, W. E. Holben, and J. E. Gannon, "Choice of methods for soil microbial community analysis: PLFA maximizes power compared to CLPP and PCRbased approaches," Pedobiologia, vol. 50, no. 3, pp. 275-280, 2006.

[12] Å. Frostegård, A. Tunlid, and E. Bååth, "Use and misuse of PLFA measurements in soils," Soil Biology and Biochemistry, vol. 43, no. 8, pp. 1621-1625, 2011.

[13] S. R. Dangi, P. D. Stahl, E. Pendall, M. B. Cleary, and J. S. Buyer, "Recovery of soil microbial community structure after fire in a sagebrush-grassland ecosystem," Land Degradation and Development, vol. 21, no. 5, pp. 423-432, 2010.

[14] S. R. Dangi, P. D. Stahl, A. F. Wick, L. J. Ingram, and J. S. Buyer, "Soil microbial community recovery in reclaimed soils on a surface coal mine site," Soil Science Society of America Journal, vol. 76, no. 3, pp. 915-924, 2012. 
[15] L. Zelles, A. Palojärvi, E. Kandeler, M. Von Lützow, K. Winter, and Q. Y. Bai, "Changes in soil microbial properties and phospholipid fatty acid fractions after chloroform fumigation," Soil Biology and Biochemistry, vol. 29, no. 9-10, pp. 1325-1336, 1997.

[16] M. E. Stromberger, S. Klose, H. Ajwa, T. Trout, and S. Fennimore, "Microbial populations and enzyme activities in soils fumigated with methyl bromide alternatives," Soil Science Society of America Journal, vol. 69, no. 6, pp. 1987-1999, 2005.

[17] S. Gao, B. D. Hanson, R. Qin, D. Wang, and S. R. Yates, “Comparisons of soil surface sealing methods to reduce fumigant emission loss," Journal of Environmental Quality, vol. 40, no. 5, pp. 1480-1487, 2011.

[18] J. S. Gerik, "Evaluation of soil fumigants applied by drip irrigation for liatris production," Plant Disease, vol. 89, no. 8, pp. 883-887, 2005.

[19] H. Komada, "Development of a selective medium for quantitative isolation of Fusarium oxysporum from natural soil," Review of Plant Protection Research, vol. 8, pp. 114-125, 1975.

[20] S. N. Jeffers and S. B. Martin, "Comparison of two media selective for Phytophthora and Pythium species," Plant Disease, vol. 70, pp. 1038-1043, 1986.

[21] J. S. Buyer, J. R. Teasdale, D. P. Roberts, I. A. Zasada, and J. E. Maul, "Factors affecting soil microbial community structure in tomato cropping systems," Soil Biology and Biochemistry, vol. 42, no. 5, pp. 831-841, 2010.

[22] M. A. Cavigelli, G. P. Robertson, and M. J. Klug, "Fatty acid methyl ester (FAME) profiles as measures of soil microbial community structure," Plant and Soil, vol. 170, no. 1, pp. 99-113, 1995.

[23] A. Frostegard, A. Tunlid, and E. Baath, "Phospholipid fatty acid composition, biomass, and activity of microbial communities from two soil types experimentally exposed to different heavy metals," Applied and Environmental Microbiology, vol. 59, no. 11, pp. 3605-3617, 1993.

[24] L. Zelles, Q. Y. Bai, R. X. Ma, R. Rackwitz, K. Winter, and F. Beese, "Microbial biomass, metabolic activity and nutritional status determined from fatty acid patterns and polyhydroxybutyrate in agriculturally-managed soils," Soil Biology and Biochemistry, vol. 26, no. 4, pp. 439-446, 1994.

[25] C. B. Blackwood and J. S. Buyer, "Soil microbial communities associated with Bt and non-Bt corn in three soils," Journal of Environmental Quality, vol. 33, no. 3, pp. 832-836, 2004.

[26] SAS Institute, SAS/STAT User's Guide. Version 9.1, SAS Institute, Cary, NC, USA, 4th edition, 2003.

[27] J. S. Buyer, D. P. Roberts, and E. Russek-Cohen, "Microbial community structure and function in the spermosphere as affected by soil and seed type," Canadian Journal of Microbiology, vol. 45, no. 2, pp. 138-144, 1999.

[28] J. S. Buyer, D. P. Roberts, and E. Russek-Cohen, "Soil and plant effects on microbial community structure," Canadian Journal of Microbiology, vol. 48, no. 11, pp. 955-964, 2002.

[29] G. A. F. Seber, Multivariate Observations, John Wiley \& Sons, New York, NY, USA, 1984.

[30] L. G. Miller, T. L. Connell, J. R. Guidetti, and R. S. Oremland, "Bacterial oxidation of methyl bromide in fumigated agricultural soils," Applied and Environmental Microbiology, vol. 63, no. 11, pp. 4346-4354, 1997.

[31] J. L. Macalady, M. E. Fuller, and K. M. Scow, "Effects of metam sodium fumigation on soil microbial activity and community structure," Journal of Environmental Quality, vol. 27, no. 1, pp. 54-63, 1998.
[32] J. S. Gerik and B. D. Hanson, "Drip application of methyl bromide alternative chemicals for control of soilborne pathogens and weeds," Pest Management Science, vol. 67, no. 9, pp. 11291133, 2011.

[33] V. Acosta-Martínez, T. M. Zobeck, and V. Allen, "Soil microbial, chemical and physical properties in continuous cotton and integrated crop-livestock systems," Soil Science Society of America Journal, vol. 68, no. 6, pp. 1875-1884, 2004.

[34] S. Yao, I. A. Merwin, G. S. Abawi, and J. E. Thies, "Soil fumigation and compost amendment alter soil microbial community composition but do not improve tree growth or yield in an apple replant site," Soil Biology and Biochemistry, vol. 38, no. 3, pp. 587-599, 2006.

[35] F. N. Martin, "Development of alternative strategies for management of soilborne pathogens currently controlled with methyl bromide," Annual Review of Phytopathology, vol. 41, pp. 325350, 2003.

[36] F. Inagaki, Y. Sakihama, A. Inoue, C. Kato, and K. Horikoshi, "Molecular phylogenetic analyses of reverse-transcribed bacterial rRNA obtained from deep-sea cold seep sediments," Environmental Microbiology, vol. 4, no. 5, pp. 277-286, 2002.

[37] M. N. Nielsen and A. Winding, Microorganisms As Indicators of Soil Health, National Environmental Research Institute, Roskilde, Denmark, 2002.

[38] K. K. Treseder and M. F. Allen, "Mycorrhizal fungi have a potential role in soil carbon storage under elevated $\mathrm{CO}_{2}$ and nitrogen deposition," New Phytologist, vol. 147, no. 1, pp. 189200, 2000.

[39] C. A. McClaugherty, J. Pastor, J. D. Aber, and J. M. Melillo, "Forest litter decomposition in relation to soil nitrogen dynamics and litter quality," Ecology, vol. 66, no. 1, pp. 266-275, 1985.

[40] W. M. Post, J. Pastor, P. J. Zinke, and A. G. Stangenberger, "Global patterns of soil nitrogen storage," Nature, vol. 317, no. 6038, pp. 613-616, 1985.

[41] M. E. Ragab and K. A. Okasha, "Effect of soil fumigation with methyl bromide on mineral nutrition of strawberry," in Proceedings of the 91st Annual Meeting of the American Society for Horticultural Science, Oregon State University, Corvallis, Ore, USA, August 1994. 

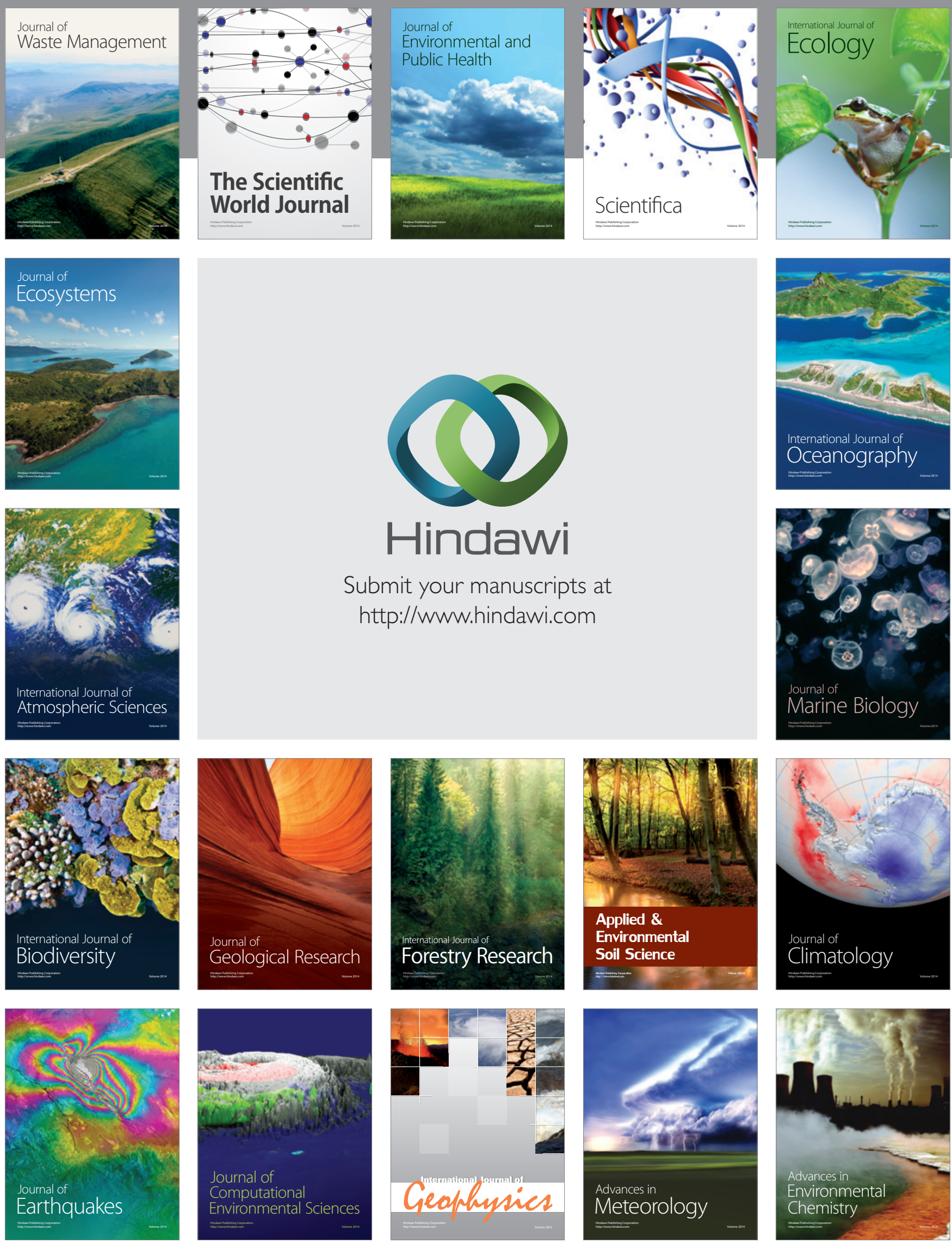